JIKAP PGSD: Jurnal IImiah Ilmu Kependidikan

Vol,1. No,1. Tahun 2017

e-ISSN: 2597-4440 dan p-ISSN: 2597-4424

(c) (1) This work is licensed under a Creative Commons Attribution

4.0 International License

\title{
Penerapan Model Pembelajaran Inside Outside Circle Dalam Meningkatkan Hasil Belajar IPS Siswa Kelas IV SD Negeri 215 Kading Kecamatan Barebbo Kabupaten Bone
}

\author{
${ }^{1}$ ST Jauhar, ${ }^{3}$ Abdul Kadir, ${ }^{3}$ Wahyuni \\ ${ }^{12}$ Fakultas Ilmu Pendidikan, UNM \\ Email: ${ }^{1}$ nesyaamran@yahoo.co.id \\ Email: ${ }^{2}$ wahyunifahruddin24@gmail.com \\ Email: 2Jauhar@unm.ac.id
}

\begin{abstract}
Abstrak. Tujuan penelitian ini adalah mendeskripsikan penerapan model pembelajaran Inside Outside Circle dalam meningkatkan Hasil belajar IPS Siswa Kelas IV SD Negeri 215 Kading Kecamatan Barebbo Kabupaten Bone. Pendekatan penelitian menggunakan pendekatan kualitatif deskriptif dan jenis penelitian ini merupakan penelitian tindakan kelas meliputi perencanaan, pelaksanaan, observasi dan refleksi. Fokus penelitian ini dilihat dari (1) Model pembelajaran Inside Outside Circle dan (2) Hasil belajar siswa. Subjek penelitian ini adalah seluruh siswa kelas IV SD Negeri 215 Kading Kecamatan Barebbo Kabupaten Bone. Teknik pengumpulan data dilakukan dengan observasi, tes dan dokumentasi. Teknik analisis data meliputi merduksi data, penyajian data, dan penarikan kesimpulan. Penarikan kesimpulan data yang diperoleh dari hasil penelitian menunjukkan bahwa hasil belajar IPS siswa setelah dilakukan penerapan model pembelajaran Inside Outside Circle mengalami peningkatan yaitu dari siklus I dengan kategori cukup dan siklus II dengan kategori baik. Kesimpulan dari penelitian ini adalah dengan menerapkan model pembelajaran Inside Outside Circle dapat meningkatkan hasil belajar siswa dalam pembelajaran IPS.
\end{abstract}

Kata Kunci : Model pembelajaran Inside Outside Circle, Hasil Belajar, IPS

\begin{abstract}
Target of this research is applying mendeskripsikan model study of Inside Outside Circle in improving Result learn IPS Student Class IV SD Country 215 Kading District of Barebbo Sub-Province Bone. Approach of Research use descriptive approach qualitative and this research type represent research of class action cover planning, execution, refleksi and observation. Focus this research [is] seen from ( 1) Model study of Inside Outside Circle and (2) Result learn student. this Research Subjek is entire/all IV SD Country class student 215 Kading District of Barebbo Sub-Province Bone. Technique data collecting conducted with observation, documentation and tes. Technique analyse data cover data merduksi, presentation data, and withdrawal conclusion. obtained data from result of research indicate that result learn IPS student after done by applying model study Inside Outside Circle experience of improvement that is from I cycle with category enough and II cycle with good category. Conclusion from this research [is] by applying model study Inside Outside Circle can improve result learn student in study [IPS
\end{abstract}

Keyword : Model study of Inside Outside Circle, Result of Learning, IPS 


\section{PENDAHULUAN}

Upaya meningkatkan mutu pendidikan diarahkan pada penataan proses pembelajaran yang dibenahi secara seksama. Proses pembelajaran yang dimaksud terdiri dari beberapa komponen yang terkait satu sama lain dalam usaha pencapaian tujuan pembelajaran seperti rencana pelakasanaan pembelajaran, media pembelajaran, teknik pembelajaran sampai pada pemberian evaluasi. Pendidikan sangatlah penting artinya, sebab tanpa pendidikan, manusia akan sulit berkembang dan bahkan terbelakang. Dengan demikian, pendidikan harus benar-benar diharapkan untuk menghasilkan manusia yang berkualitas dan mampu bersaing, disamping memiliki budi pekerti yang luhur dan moral yang baik. Hal ini sesuai dengan tujuan pendidikan dalam Undang-Undang No. 20 tahun 2003 tentang Sistem Pendidikan Nasional Depdiknas, (2003 : 7) yang menyatakan:

\begin{abstract}
"Pendidikan adalah usaha sadar dan terencana untuk mewujudkan suasana belajar dan proses pembelajaran agar siswa secara aktif mengembangkan potensi dirinya untuk memiliki kekuatan spiritual, keagamaan, pengendalian diri, kepribadian, kecerdasan, akhalak mulia serta keterampilan yang diperlukan dirinya, masyarakat, bangsa dan Negara".
\end{abstract}

Mata pelajaran IPS dirancang untuk mengembangkan kemampuan siswa agar menjadi anggota masyarakat yang memiliki pengetahuan, pemahaman dan kemampuan analisis terhadap kondisi sosial masyarakat dalam memasuki kehidupan bermasyarakat yang dinamis. Dalam Kurikulum Tingkat Satuan Pendidikan (KTSP) 2006 tercantum bahwa salah satu tujuan pengajaran IPS di SD adalah "memiliki komitmen dan kesadaran terhadap nilai-nilai sosial dan kemanusiaan".

Ilmu Pengetahuan Sosial merupakan pelajaran yang meliputi wawasan, namun tanpa pengaplikasian yang baik hanya akan menghasilkan individu-individu yang egois dan kurang bertanggung jawab. Harapan bangsa terhadap pendidikan yaitu untuk mewujudkan pendidikan yang mampu menjadi warga negara yang baik, menghasilkan penerus bangsa sebagai pemimpin yang cerdas. Maka dari itu, seharusnya dalam pembelajaran IPS di sekolah-sekolah perlu pembelajaran yang mengesankan untuk siswa sehingga siswa diharapkan mampu berfikir kritis dan pembelajaran dapat bermakna.

Mutakin (Susanto, 2013 : 145-146) merumuskan tujuan pembelajaran IPS di sekolah, sebagai berikut:

(1)Memiliki kesadaran dan kepedulian terhadap masyarakat atau lingkungannya, melalui pemahaman terhadap nilai-nilai sjarah dan kebudayaan masyarakat; (2) Mengetahui dan memahami konsep dasar dan mampu menggunakan metode yang diadaptasi dari ilmu-ilmu sosial yang kemudian dapat digunakan untuk memecahkan masalahmasalah sosial; (3) Mampu menggunakan model-model dan proses berpikir serta membuat keputusan untuk menyelesaikan isu dan masalah yang berkembang dimasyarakat; (4) menaruh perhatian terhadap isu-isu dan masalah-masalah sosial, serta mampu membuat analisis yang kritis, selanjutnya mampu mengambil tindakan yang tepat; (5) Mampu mengembangkan berbagai potensi sehingga mampu membangun diri sendiri agar survive yang kemudian bertanggung jawab membangun masyarakat.

Pelaksanaan pembelajaran IPS, seorang guru tentu dituntut memiliki kemampuan dan kreativitas yang cukup agar pembelajaran dapat terselenggarakan secara efektif dan efesien. Salah satu aspek kemampuan yang harus dimiliki oleh seorang guru adalah tentang pemahaman dan penguasaan terhadap penerapan model yang efektif dan cocok diaplikasikan dalam proses pembelajaran IPS agar siswa mudah memahami serta menguasai materi yang diajarkan. Melalui model pembelajaran yang akan dilaksanakan oleh guru maka hasil belajar siswa meningkat.

Berdasarkan hasil observasi yang dilaksanakan pada hari jumat dan sabtu tanggal 27 - 28 Januari 2017 di kelas IV SD Negeri 215 Kading Kecamatan Barebbo Kabupaten Bone, maka peneliti menemukan fakta yang terdapat di dalam kelas, yaitu : (1) Guru kurang memberi kesempatan kepada siswa untuk bertanya sehingga siswa kurang aktif dalam proses 
pembelajaran; (2) Guru kurang menciptakan kondisi kelas yang menyenangkan sehingga siswa kurang bersemangat dalam belajar; (3) Guru kurang mengaitkan pelajaran dengan kehidupan nyata sehingga siswa kurang antusias dalam mengikuti proses pembelajaran; (4) Guru kurang menggunakan media pembelajaran sehingga siswa kurang menalar pada saat guru menjelaskan materi pembelajaran.

Pada hasil observasi yang dipaparkan dapat diketahui hasil belajar IPS di kelas IV sesuai dengan dokumentasi di sekolah dari hasil Ulangan Semester Ganjil Tahun Pelajaran 2016/2017. Nilai rata-rata kelas IV hanya mencapai $62,14 \%$ dari 14 siswa, hanya 5 $(35,71 \%)$ siswa yang memenuhi standar KKM dan 9 (64,28\%) siswa dibawah standar KKM. Dengan demikian, nilai IPS tergolong rendah dari nilai 70 sebagai standar Kriteria Ketuntasan Minimal.

Jika permasalahan tersebut dibiarkan secara terus menerus, akan mempengaruhi atau berdampak pada hasil belajar siswa dalam pembelajaran IPS yang pada gilirannya secara terus menerus akan menurunkan hasil belajar siswa. Oleh karena itu, untuk memecahkan masalah tersebut diatas, peneliti bersama guru akan mengkolaborasi penyebab masalah-masalah yang ditemukan oleh peneliti untuk menentukan cara pemecahan atau penanggulangannya dengan menggunakan model pembelajaran Inside Outside Circle dalam meningkatkan hasil belajar IPS siswa kelas IV SD Negeri 215 Kading Kecamatan Barebbo Kabupaten Bone.

Model pembelajaran Inside Outside Circle sangat efektif dalam meningkatkan potensi dan tingkat pemahaman pada siswa karena model pembelajaran Inside Outside Circle dapat digunakan untuk memberikan kesan mendalam pada proses belajar siswa karena pola belajarnya yang unik sehingga siswa mudah mengingat informasi yang akan dia sampaikan kepada teman pasangannya. Selain itu model pembelajaran Inside Outside Circle juga memberikan siswa banyak kesempatan untuk mengolah informasi dan meningkatkan keterampilan berkomunikasi. Model ini membuat proses pembelajaran menjadi menarik karena skenario pembelajarannya yang membagi siswa menjadi beberapa kelompok kemudian masingmasing kelompok membentuk lingkaran dalam dan lingkaran luar sehingga siswa mempunyai pasangan dan saling berhadapan. Setiap pasangan itu saling berbagi informasi setelah berbagi informasi dengan pasangannya, siswa yang di lingkaran luar bergeser dan mendapatkan pasangan lain kemudian berbagi informasi lagi, begitu seterusnya sampai kembali kepasangan awal. Model ini cocok digunakan dalam pembelajaran IPS karena pembelajaran IPS memiliki cakupan isi/materi yang cukup banyak sehingga memudahkan guru untuk membagi materi sesuai dengan siswa yang membentuk lingkaran, karena masing-masing anak membawa informasi yang berbeda untuk teman pasangannya, sehingga siswa dapat memahami keseluruhan materi secara utuh.

Berdasarkan uraian di atas maka peneliti dalam kesempatan ini melakukan sebuah Penelitian Tindakan Kelas (PTK) dengan judul Penerapan Model Pembelajaran Inside Outside Circle dalam meningkatkan hasil belajar IPS kelas IV SD Negeri 215 Kading Kecamatan Barebbo Kabupaten Bone.

\section{METODE PENELITIAN}

a. Jenis Penelitian

Jenis penelitian ini adalah Penelitian Tindakan Kelas (PTK). Menurut Arikunto ( 2014 : 3) bahwa "Penelitian Tindakan Kelas merupakan suatu pencermatan terhadap kegiatan belajar berupa sebuah tindakan, yang sengaja dimunculkan dan terjadi dalam sebuah kelas secara bersama".

Penelitian Tindakan Kelas memiliki karakteristik dirumuskan oleh (Muslich, 2014: 45) "pelaksanaan tidakan dalam penelitian ini dilaksanakan secara berdaur (siklus) ulang". Apabila pada siklus I sudah bias mencapai tujuan yang diinginkan maka langsung dapat ditarik kesimpulan, tetapi jika masih ada perbaikan, atau metode yang digunakan tidak berhasil maka dilanjutkan dengan tindakan selanjutnya.

Sehubungan dengan hal tersebut Arikunto (2014:58) berpendapat bahwa "penelitian tindakan kelas dilakukan dengan bertujuan memperbaiki atau meningkatan mutu praktik pembelajaran".

Berdasarkan dari beberapa pendapat tersebut diatas, maka dalam penelitian tindakan kelas ini akan dilakukan secara berkolaborasi dengan guru kelas di SD Negeri 215 Kading Kecamatan Barebbo Kabupaten Bone dalam usaha memperbaiki proses pembelajaran untuk meningkatkan hasil belajar siswa.

b. Setting Penelitian

Penelitian ini dimulai pada semester genap termasuk juga kegiatan pembelajaran yang 
dilaksanakan di SD Negeri 215 Kading Kecamatan Barebbo Kabupaten Bone. Adapun letak kelas IV yaitu di ujung kiri dari kelas VI. Kondisi dalam keadaan normal dan terdapat 1 buah papan tulis, 1 buah meja guru, 7 meja dan 14 kursi siswa.

c. Fokus Penelitian

Penelitian yang dilaksanakan di SD Negeri 215 Kading Kecamatan Barebbo Kabupaten Bone difokuskan pada :

a. Model pembelajaran Inside Outside Circle adalah model pembelajaran dengan sistem lingkaran kecil dan lingkaran besar yang dimana siswa saling membagi informasi pada saat yang bersamaan dengan pasangan yang berbeda dengan singkat dan teratur.

b. Hasil belajar yang dimaksud adalah nilai yang diperoleh oleh siswa dalam pembelajara IPS setelah diterapkan model pembelajaran Inside Outside Circle. Nilai tersebut melalui tes yang diadakan di setiap akhir siklus.

d. Teknik Pengumpulan Data

Teknik pengumpulan data dalam penelitian ini yaitu, observasi, tes, dokumentasi.

e. Analisis Data

Analisis data dilakukan dengan cara mengelompokkan data aspek guru dan aspek siswa. Teknik yang digunakan adalah teknik analisis data kualitatif menurut Miles dan Huberman (Sugiyono, 2008 : 338) yang terdiri dari tiga tahap kegiatan yaitu Mereduksi Data, Penyajian Data, dan Menarik Kesimpulan.

\section{HASIL DAN PEMBAHASAN}

Pada bagian ini dibahas tentang data-data yang diperoleh selama pelaksanaan tindakan dengan penerapan model pembelajaran Inside Outside Circle dalam pembelajaran IPS. Fokus pembahasannya yaitu pelaksanaan pembelajaran (aktivitas peneliti) dan siswa SD Negeri 215 Kading Kecamatan Barebbo Kabupaten Bone dengan menggunakan model pembelajaran Inside Outside Circle dalam memahami pengertian dan sifat-sifat koperasi, jenis-jenis koperasi dan usahanya, manfaat, prinsip dan modal koperasi, tujuan dan alasan diperlukannya koperasi di sekolah . Menurut Shoimin (2014 : 87) menyatakan bahwa model pembelajaran Inside Outside Circle adalah model pembelajaran dengan sistem lingkaran kecil dan lingkaran besar yang diawali dengan pembentukan kelompok besar dalam kelas yang terdiri dari kelompok lingkaran dalam dan kelompok lingkaran luar. Model ini memiliki 10 tahapantahapan pembelajaran pada umumnya yaitu 1) guru membagi siswa menjadi beberapa kelompok yang beranggotakan 3-4 orang 2) Tiap-tiap kelompok mendapatkan tugas mencari informasi berdasarkan pembagian tugas dari guru 3) Setiap kelompok belajar mandiri mencari informasi berdasarkan tugas yang diberikan 4) Setelah selesai, seluruh siswa berkumpul saling membaur (tidak berdasarkan kelompok 5) Separuh kelas lalu berdiri membentuk lingkaran kecil dan menghadap keluar 6) Separuh kelas lainnya membentuk lingkaran di luar lingkaran pertama menghadap kedalam 7) Dua siswa yang berpasangan dari lingkaran kecil dan besar berbagi informasi. Pertukaran informasi ini bisa dilakukan oleh semua pasangan dalam waktu yang bersamaan 8) Kemudian siswa berada di lingkaran kecil diam di tempat, sementara siswa yang berada di lingkaran besar begeser satu atau dua langkah searah jarum jam 9) Selanjutnya siswa berada di lingkaran besar yang membagi informasi. Demikian seterusnya sampai seluruh siswa selesai berbagai informasi 10) Pergerakan baru dihentikan jika anggota kelompok lingkaran dalam dan luar sebagai pasangan asal bertemu kembali. Sedangkan menurut Zainal Aqib (2013 : 30) model Inside Outside Circle dengan langkah-langkahnya sebagai berikut: 1) separuh siswa berdiri membentuk lingkaran kecil dan menghadap keluar; 2) separuh siswa lainnya memebntuk lingkaran diluar lingkaran pertama, menghadap kedalam; 3) dua siswa yang berpasangandari lingkaran kecil dan besar berbagi informasi. Pertukaran informasi bisa dilakukan oleh semua pasangan dalam waktu yang bersamaan; 4) kemudian siswa yang berada dilingkaran kecil diam ditempat, sementara siswa yang berada dilingkaran besar bergeser satu atau dua langkah searah jarum jam; 5) sekarang giliran siswa yang membagi informasi. Demikian seterusnya.

Dalam proses pembelajaran, guru terlebih dahulu menyampaikan tujuan pembelajaran yang akan dicapai. Kemudian, guru menjelaskan materi pelajaran kepada siswa dan menampilkan media pembelajaran. Dalam siklus I, kegiatan guru dalam menyajikan materi masih kurang, hal ini nampak pada saat guru menyajikan materi masih banyak siswa yang terlihat bingung terhadap apa yang disampaikan guru. Kegiatan selanjutnya, guru membentuk 2 kelompok besar lalu memberikan LKS kepada 
setiap kelompok untuk didiskusikan. Setelah diskusi selesai, siswa diminta untuk membentuk 2 buah lingkaran yakni lingkaran dalam dan lingkaran luar dan saling berhadapan sehingga masing-masing kelompok mendapat satu pasangan dari kelompok 2 kemudian siswa berbagi informasi satu sama lainnya, setelah itu siswa yang di lingkaran dalam diam di tempat, sementara siswa yang di lingkaran luar bergeser dan membagi informasi kepada pasangan yang berada dilingkaran kecil, pergerakan baru dihentikan sampai semuanya telah bertemu sebagai pasangan asal. Dalam hal ini, guru kurang membimbing siswa pada saat berbagi informasi sehingga sebagian dari siswa bingung, tidak tau apa yang akan dilakukan. Siswa masih ada yang bergurau saat berbagi informasi, Hal ini sesuai dengan pendapat Shoimin ( $2014: 90$ ) dalam mengemukakan salah satu kekurangan model pembelajaran Inside Outside Circle yaitu terlalu lama sehingga tidak konsentrasi dan disalah gunkan untuk bergurau. Terakhir dalam siklus I, guru masih kurang memberikan motivasi, penguatan, maupun pesan moral kepada siswa sehingga siswa kurang termotivasi dalam belajar dan tidak mengulangi pelajarannya saat di rumah.

Pada pembelajaran siklus II, semua kekurangan-kekurangan telah diperbaiki sehingga menciptakan proses pembelajaran yang efektif. Hal ini nampak pada saat pemberian materi. Pada siklus II ini, guru telah memberikan motivasi, penguatan, maupun pesan moral kepada siswa dengan baik sehingga siswa mengulang pelajarannya saat dirumah, hal ini dibuktikan oleh hasil pembelajaran siswa yang semakin meningkat di setiap pertemuan. Guru juga telah mampu mengelola kelas dengan baik dan siswa juga telah memahami langkahlangkah model pembelajaran Inside Outside Circle sehingga tercipta proses pembelajaran yang kondusif.

Hasil belajar pada siklus I ke siklus II meningkat. Berdasarkan hasil belajar pada siklus I pertemuan I, rata-rata nilai siswa hanya mencapai 64,64 dengan ketuntasan belajar kelas yaitu $50 \%$ sedangkan pertemuan II mencapai 66,78 dengan ketuntasan belajar $57,14 \%$, ini menunjukkan pada siklus I belum mencapai indikator keberhasilan yang diinginkan. Pada siklus II pertemuan I nilai rata-rata siswa telah mengalami peningkatan yaitu 70,35 dengan ketuntasan kelas 71,42\%. Meskipun telah meningkat dan tergolong baik, pencapaian indikator keberhasilan belum sesuai dengan yang diinginkan. Pada siklus II pertemuan II peningkatan hasil belajar telah mencapai indikator keberhasilan yang diinginkan yakni $\geq 71 \%$. Hal ini dilihat pada nilai rata-rata siswa yang mencapai 75,71 dengan persentase ketuntasan kelas $85,71 \%$.

\section{SIMPULAN}

Berdasarkan hasil temuan penelitian ini, maka hasil penelitian ini dapat disimpulkan bahwa ada 8 langkah-langkah model pembelajaran Inside Outside Circle sudah berjalan dengan baik dan dapat meningkatkan hasil belajar IPS siswa kelas IV SD Negeri 215 Kading Kecamatan Barebbo Kabupaten Bone. Hal ini dibuktikan dengan hasil belajar yang dicapai siswa pada tes siklus I dengan kategori cukup (C) meningkat pada siklus II menjadi kategori baik (B).

\section{DAFTAR RUJUKAN}

Arikunto, Suharsimi, Suhardjono, dan Supardi. 2015. Penelitian Tindakan Kelas. Jakarta: Bumi Aksara

Arikunto, Suharsimi dan Cepi Safruddin. 2007. Evaluasi Program Pendidikan. Jakarta : Bumi Aksara.

Depdiknas. 2006. Kurikulum Tingkat Satuan Pendidikan (KTSP) untuk SD/MI. Jakarta: Depdiknas.

-----. 2003. Undang-Undang No. 20 Tahun 2003 tentang Sistem Pendidikan Nasional

Gunawan, Imam. 2014. Metode Penelitian kualitatif Teori \& Praktik.Jakarta : Bumi Aksara

Gunawan, Rudy. 2011. Pendidikan IPS Filosofi, Konsep dan Aplikasi. Bandung: Alfabeta

Huda, Miftahul. 2014. Model-Model Pengajaran dan Pembelajaran. Yogyakarta : Pustaka Belajar.

Jihad, Asep dan Haris, Abdul. 2013. Evaluasi Pembelajaran .Yogyakarta : Multi Pressindo. 
JIKAP PGSD: Jurnal Ilmiah Ilmu Kependidikan

Kurniasih, Imas dan Berlin Sani. 2015. Ragam Pengembangan Model Pembelajaran. Jakarta : Kata Pena.

Sinring, dkk. 2012. Panduan Penulisan Skripsi Program S-1 FIP UNM. Universitas Negeri Makassar.

Shoimin, Aris. 2014. 68 Model Pembelajaran Inovatif Dalam Kurikulum 2013. Yogyakarta : Ar-Ruzz Media.

Sugiyono. 2008. Memahami Penelitian Kualitatif. Bandung: Alfabeta.

Susanto, Ahmad. 2013. Teori belajar dan pembelajaran di Sekolah Dasar. Jakarta: Kencana Prenada Media Grup.

Suprijono, Agus. 2009. Cooperative Learning "Teori dan Aplikasi Paikem”.Yogyakarta. Pustaka Belajar.

Taniredja, Tukiran, dkk. 2011. Model-model Pembelajaran Inovatif. Bandung. Alfabeta 